\title{
USING COMMON FEATURES TO INVESTIGATE COMMON GROWTH CYCLES FOR BRICS COUNTRIES
}

\author{
Bruno Ricardo Delalibera* \\ JoÃo Victor ISSLER ${ }^{\dagger}$ \\ Roberto Castello Branco ${ }^{\ddagger}$
}

\begin{abstract}
Resumo
Utilizando técnicas econométricas sugeridas pela literatura de ciclos comuns, este artigo estuda os movimentos comuns de curto e de longo prazo dos países pertencentes ao BRICS. Apesar das suas diferenças, nos últimos 20 anos as relações comercias entre os BRICS se fortaleceram, sugerindo um possível componente comum entre os ciclos dos países membros. Os nossos resultados suportam essa hipótese. A evidência também é válida entre os BRICS e algumas economias desenvolvidas, como os Estados Unidos e o bloco de países que formam a Zona do Euro.
\end{abstract}

Palavras-chave: Ciclos Comuns; BRICS; Economias emergentes.

\begin{abstract}
This paper examines the short and long-term co-movement of large emerging market economies - the BRICS countries - by applying the econometric techniques and the tests proposed in the common-feature literature. Despite their dissimilarities, given the rising trade linkages among the BRICS over the last 20 years, one should expect their cycles to be synchronized. Our empirical findings fully support this hypothesis. The evidence holds also for the co-movement between the BRICS and developed economies, the US and the Eurozone, which may reflect the effects of globalization. We believe that our results contribute to give an interesting insight into the short-term dynamics of the largest emerging market economies.
\end{abstract}

Keywords: Common cycles; BRICS; Emerging Markets.

JEL classification: C3, C5, F44

DOI: http://dx.doi .org/10.11606/1413-8050/ea116259

\footnotetext{
* FGV/EPGE Brazilian School of Economics and Finance. Email: bruno.delalibera@fgvmail.br

† Corresponding Author. FGV/EPGE Brazilian School of Economics and Finance. Email: joao.issler@fgv.br

‡ FGV - Growth and Development Center. Email: roberto.cbranco@fgv.br
} 


\section{Introduction}

The term BRIC was coined in 2001 by Jim O'Neil, then Chief Economist of Goldman Sachs, from the initials of the four largest emerging market economies, Brazil, Russia, India and China. More recently, South Africa was added to the original group, and the acronym BRICS gained formal life as a bloc of nations with common interests.

The BRICS are important ${ }^{1}$, for both political and economic reasons. China is the second largest economy in the world, while Brazil, India and Russia are among the ten largest economies. They have a large aggregate size, $28 \%$ of the global GDP and $42 \%$ of the world's population, high growth potential due to the current significant misallocation of resources and relatively low stock of human capital, structural transformation is in progress, and one of them, China is taking steps to become a global power and a challenger to the US dominance. Furthermore, the BRICS share in global investment is $40 \%$ while its share in global consumption is $20 \%$.

Despite the popularity of the name BRICS, little is known about the economic similarities and differences among member countries. This paper takes an exploratory view of the subject. Its purpose is to look for similarities among BRICS countries (Brazil, Russia, India, China and South Africa) by using standard time-series techniques. Since the growth experiences of the member countries are very different, our focus will be on the cyclical similarities among them.

We propose studying this issue by using an integrated approach that models jointly the short- and the long-run behavior of member countries. Specifically, we employ tests of synchronicity of cycles of key economic variables of the BRICS countries, put forward by the common-trend and common-cycle approach of Engle \& Kozicki (1993), Vahid \& Engle (1993, 1997), Engle \& Issler (1995), Issler \& Vahid (2001, 2006), Vahid \& Issler (2002), Hecq et al. (2006), and Athanasopoulos et al. (2011). In this setup, non-stationary economic series are decomposed into an integrated trend component and a stationary and ergodic cyclical component, where their properties can be jointly investigated in a unified multivariate setting based on vector autoregressive (VAR) models. Trends and cycles can be common to a group of series being modelled, and these common features can be removed by independent linear combination ${ }^{2}$.

Our exaustive econometric tests found that BRICS countries have similar gross domestic product (GDP) cycles - common GDP cycles -, consumption, investment, and industrial production cycles, which is in line with previous evidence comparing emerging and developed economies.; see, for example, the initial results in Calvo et al. (1993), Engle \& Issler (1993), and, recently, the results in Aiolfi et al. (2011).

\footnotetext{
${ }^{1}$ The BRICS began to act as a bloc, sharing some joint political positions involving selected issues. The main decision of the Fortaleza summit of july 2014 was the creation of two financial instruments to institutionalize and strengthen the financial relationship within the bloc. These instruments are: (i) The contingent Reserve Agreement (CRA) is dedicated to deal with shortterm balance of payments disequilibria through currency swap lines amounting to US $\$ 100$ bilion supplied by the BRICS central banks; and (ii) The New Development Bank (NDB) has an initial capital of US $\$ 50$ bilion, to be subscribed equally by the five BRICS, and an authorized capital of US\$ 100 billion. The NDB will be headquartered in Shanghai, China, with a regional office in Joahnnesburg, South Africa. Its purpose is to finance infrastructure and sustainable development in the BRICS and other emerging economies.

${ }^{2}$ Perhaps cointegration is the best-known example of common features.
} 
The paper is divided as follows: Section 2 presents a brief summary of the recent growth experiences of BRICS countries, Section 3 presents the econometric techniques employed here, while the empirical results are reported in detail in Section 4. Section 5 presents the conclusions.

\section{Growth Experiences of the BRICS countries}

Brazil, India, China, Russia and South Africa share the usual characteristics of emerging economies. However, they have many dissimilarities. The extraordinary expansion of the BRICS over the last decades was primarily due to the high growth rates of China and India, as Brazil, Russia and South Africa grew in line with the global GDP pace.

During 1990-2013, the BRICS share in global GDP climbed from $18 \%$ to $28 \%$. This is explained by the high growth performance of China and India, $10.3 \%$ and $6.7 \%$ per year, respectively. Brazil and South Africa had a slower pace of growth, averaging approximately 3\% per year. Russia's rate of economic growth was about the same. However, its economy is too volatile, even by the standards of emerging market economies.

The Russian economy is the most volatile of the BRICS economies ${ }^{3}$, being three times more volatile than the others. This phenomenon may be explained by the large exposure to commodities, primarily oil and gas, and its tendency to be involved in geopolitical disputes.

Between 1990 and 2013, China and India were the two economies to show some convergence to the US income level, even though Indian per capita GDP is still only $9 \%$ of the American. Relative GDP per capita of Brazil, Russia and South Africa have remained stable at approximately 20\%. Despite its extraordinary growth experience over the last 35 years, China's per capita GDP is still below $20 \%$ of the US. When compared to other Asian economies that experienced rapid expansion in the second half of the last century, China lags well behind in terms of convergence to the income level of developed countries, as it started from a very low basis, US\$ 150 in 1978 , only $2 \%$ of the $\mathrm{US}^{4}$.

Brazil managed to expand at a fast pace between 1950 and 1980, when real GDP grew at an average rate of $7.8 \%$, mostly influenced by structural transformation, the reallocation of resources from the low-productivity agricultural sector to higher productivity industrial and services sectors ${ }^{5}$. Since then, TFP has fallen continuously during the 80's and 90's, in synch with the so-called Latin American productivity disaster and, as a consequence, the rate of output expansion took a nosedive ${ }^{6}$. There was some recovery in the last decade, but it was interrupted by a severe recession in the recent years.

There are several economic differences among the BRICS. There are significant differences in size, per capita income, total factor productivity, demogra-

\footnotetext{
${ }^{3}$ Emerging economies tend to be more volatile than the developed, and in particular they use to suffer larger real output and investment losses during recessions. In Kose \& Prasad (2010) we can see empirical evidence about this.

${ }^{4}$ For example, after a 30-year period of fast growth, Japan's per capita GDP was $75 \%$ of the US in 1980, and South Korea reached 46\% in 1994.

${ }^{5}$ The pace of Brazil's expansion was similar to what had been experienced by Japan in the same period and China between 1978 and 2008.

${ }^{6}$ See Veloso et al. (2013).
} 
phy, poverty levels, and aggregate demand and supply structure ${ }^{7}$. China is by far the largest economy - with a GDP measured at PPP of US\$16.1 trillion in 2013 -, and South Africa the smallest, the only BRICS economy with a GDP lower than US\$ 1 trillion. Given the dimensions of its economy, we could say that the main force of the BRICS is China ${ }^{8}$. It is the second largest economy in the world, the largest consumer of energy and minerals, the world's largest exporter of goods and services and the second largest importer, the second largest recipient of FDI flows, and the country with the largest stock of international reserves ${ }^{9}$.

Economic integration within the bloc is primarily through the trade channel, taking advantage of the complementarity between commodity exporters - Brazil, Russia and South Africa - and commodity importers - China and India. With the exception of Brazil, BRICS economies are open to international trade flows of goods and services, showing an average trade flow to GDP ratio above $50 \%$, similar to open developed economies. China is the world's largest exporter and Russia is the eighth largest. China is the second largest importer of the world and India the eighth largest ${ }^{10}$.

Intragroup trade linkages have been rising at a fast pace, taking advantage of some sources of complementarity among them. Brazil, Russia and South Africa are major commodity exporters, China is world's largest commodity importer, and India is also a major buyer. China is the largest manufacturer in the world, while India is a large exporter of services. Therefore, complementarity is likely to be a major factor influencing rising intragroup trade linkages.

Table 1 presents the intra BRICS trade for 2000 and 2013. From 2000 to 2013, there was a clear evolution of trade among BRICS countries. China was the 12th largest importer of Brazil, which had $2 \%$ of its exports destined to China, while Brazil was only the 26th largest importer of China, which had $0.5 \%$ of its exports destined to Brazil. For 2013, there was a different picture. China jumped to the main destination for Brazilian exports, receiving $19 \%$ of Brazilian exports, and Brazil became the 16th largest importer of China. In 2013, China was also the main destination for Russian exports, the second largest for South African exports, and the third largest for the exports of India.

With varying degrees, BRICS are relatively open to inbound and outbound flows of capital, both portfolio and FDI. Their FDI inflows and outflows to the rest of the world surged to US\$ 389 billion in 2012 from US\$ 70 billion in 2000. China is becoming a global investor, beginning to recycle its current

\footnotetext{
${ }^{7}$ Furthermore, there are diverse experiences with market-oriented economies, which may contribute to magnify the differences in macroeconomic performance. For instance, Russia abandoned communism almost 25 years ago, but the country still has not been able to build robust institutions to allow for the flourishment of democracy and a market economy free from heavy state intervention. China is still ruled by communism, but has a vibrant private sector and has recently officially declared market forces to play a dominant role in its economy.

${ }^{8}$ Chinese GDP is responsible for $54 \%$ of the BRICS aggregate GDP. The size of its economy is more than twice India's GDP, and almost five times Brazil and Russia as well. The South African economy, the smallest partner, had a GDP of US\$ 662 billion, only $2 \%$ of the group. China contributes with some $70 \%$ of the BRICS investment and exports.

${ }^{9}$ Chinese investment in human capital is also noteworthy. In Freeman \& Huang (2015) we can see that China became the world's largest producer of science and engineering graduates (masters and PhDs), the second largest spender on R\&D and the second largest producer of scientific papers.

${ }^{10}$ Brazil is an exception among the BRICS, as it is one the most closed economies in the world. Trade flows of goods and services reach only $28 \%$ of Brazil's GDP, the lowest in Latin America.
} 
Table 1: International trade among BRICS countries for 2000 and 2013

\begin{tabular}{|c|c|c|c|c|c|c|c|c|c|c|c|}
\hline \multicolumn{12}{|c|}{ Position of importers in the rank of trader partners } \\
\hline \multicolumn{2}{|l|}{ Exporters } & \multicolumn{4}{|c|}{ Importers at 2000} & \multicolumn{2}{|l|}{ Exporters } & \multicolumn{3}{|c|}{ Importers at 2013} & \multirow[b]{2}{*}{ ZAF } \\
\hline Country & BRA & $\mathrm{CHN}$ & IND & RUS & ZAF & Country & BRA & $\mathrm{CHN}$ & IND & RUS & \\
\hline BRA & - & $\begin{array}{c}12^{\circ} \\
{[0.0200]}\end{array}$ & $\begin{array}{c}41^{\circ} \\
{[0.0040]}\end{array}$ & $\begin{array}{c}23^{\circ} \\
{[0.0080]}\end{array}$ & $\begin{array}{c}30^{\circ} \\
{[0.0050]}\end{array}$ & BRA & - & $\begin{array}{c}1^{o} \\
{[0.1900]}\end{array}$ & $\begin{array}{c}19^{\circ} \\
{[0.0130]}\end{array}$ & $\begin{array}{c}21^{\circ} \\
{[0.0120]}\end{array}$ & $\begin{array}{c}33^{\circ} \\
{[0.0080]}\end{array}$ \\
\hline $\mathrm{CHN}$ & $\begin{array}{c}26^{\circ} \\
{[0.0050]}\end{array}$ & - & $\begin{array}{c}21^{\circ} \\
{[0.0060]}\end{array}$ & $\begin{array}{c}18^{\circ} \\
{[0.0100]}\end{array}$ & $\begin{array}{c}29^{\circ} \\
{[0.0040]}\end{array}$ & $\mathrm{CHN}$ & $\begin{array}{c}16^{\circ} \\
{[0.0160]}\end{array}$ & - & $\begin{array}{c}10^{\circ} \\
{[0.0219]}\end{array}$ & $\begin{array}{c}8^{0} \\
{[0.0224]}\end{array}$ & $\begin{array}{c}27^{\circ} \\
{[0.0800]}\end{array}$ \\
\hline IND & $\begin{array}{c}34^{\circ} \\
{[0.0050]}\end{array}$ & $\begin{array}{c}16^{\circ} \\
{[0.0170]}\end{array}$ & - & $\begin{array}{c}11^{\circ} \\
{[0.0200]}\end{array}$ & $\begin{array}{c}31^{\circ} \\
{[0.0070]}\end{array}$ & IND & $\begin{array}{c}13^{\circ} \\
{[0.0180]}\end{array}$ & $\begin{array}{c}3^{o} \\
{[0.0490]}\end{array}$ & - & $\begin{array}{c}35^{\circ} \\
{[0.0070]}\end{array}$ & $\begin{array}{c}16^{\circ} \\
{[0.0170]}\end{array}$ \\
\hline RUS & $\begin{array}{c}44^{\circ} \\
{[0.0025]}\end{array}$ & $\begin{array}{c}4^{o} \\
{[0.0500]}\end{array}$ & $\begin{array}{c}26^{\circ} \\
{[0.0100]}\end{array}$ & - & $\begin{array}{c}86^{\circ} \\
{[0.0003]}\end{array}$ & RUS & $\begin{array}{c}39^{\circ} \\
{[0.0040]}\end{array}$ & $\begin{array}{c}2^{0} \\
{[0.0680]}\end{array}$ & $\begin{array}{c}19^{\circ} \\
{[0.0130]}\end{array}$ & - & $\begin{array}{c}79^{\circ} \\
{[0.0010]}\end{array}$ \\
\hline ZAF & $\begin{array}{c}27^{\circ} \\
{[0.0080]}\end{array}$ & $\begin{array}{c}19^{\circ} \\
{[0.0130]}\end{array}$ & $\begin{array}{c}18^{\circ} \\
{[0.0140]}\end{array}$ & $\begin{array}{c}59^{\circ} \\
{[0.0010]}\end{array}$ & - & ZAF & $\begin{array}{c}32^{\circ} \\
{[0.0070]}\end{array}$ & $\begin{array}{c}1^{o} \\
{[0.1270]}\end{array}$ & $\begin{array}{c}10^{\circ} \\
{[0.0310]}\end{array}$ & $\begin{array}{c}39^{\circ} \\
{[0.0040]}\end{array}$ & - \\
\hline
\end{tabular}

Note: the share of total exports are in brackets.

Source: COMTRADE database. 
account surpluses through outbound private sector investment, rather than through reserve accumulation.

Intragroup capital flows are limited ${ }^{11}$, although they have grown in the recent years driven mostly by Chinese investments in natural resources in Russia and Brazil as well as Indian investments in manufacturing and services. More recently, and as a consequence of private sector participation, Chinese FDI outflows have been channelled also into real estate, manufacturing and services.

As evidenced by Kose \& Prasad (2010), since the mid-1980s, common global disturbances became less important in explaining international business cycles fluctuations. Given the increasing trade and financial linkages among the BRICS, it is likely that the business cycles of the BRICS tend to show common features instead of being just synchronized with global or developed economies cycles.

\section{Joint Short- and Long-Run Restriction for Dynamic Systems using VAR Models}

Parts of the material in this section come from the Appendix of Issler \& Vahid (2001) and from the discussion in Issler et al. (2014). Here, we present useful definitions of the concepts used to measure the degree of comovement in observed data. They include long-run comovement (cointegration) and short-run comovement (common cycles). Engle \& Issler (1995) and Issler \& Vahid (2001) present previous applications of the techniques discussed in this section. For an in-depth theoretical discussion of these issues, see Engle \& Granger (1987) and Vahid \& Engle (1993), respectively, for cointegration and common cycles. Theoretical extensions of the standard common-cycle case can be found in Hecq et al. (2006) and Athanasopoulos et al. (2011).

Assume that $y_{t}$ is a $n$-vector of $I(1)$ BRICS countries data, with the stationary $(M A(\infty))$ Wold representation given by:

$$
\Delta y_{t}=C(L) \epsilon_{t}
$$

where $C(L)$ is a matrix polynomial in the lag operator, $L$, with $C(0)=I_{n}$, $\sum_{j=1}^{\infty}\left\|C_{j}\right\|<\infty$. The vector $\epsilon_{t}$ is a $n \times 1$ a multivariate white noise process. We can rewrite Equation (1) as:

$$
\Delta y_{t}=C(1) \epsilon_{t}+\Delta C^{*}(L) \epsilon_{t},
$$

where $C^{*}(L)=C_{0}^{*}+C_{1}^{*} L+C_{2}^{*} L^{2}+\cdots$, with $C_{i}^{*}=\sum_{j>i}-C_{j}$ for all $i \geq 0$, and, in particular, $C_{0}^{*}=I_{n}-C(1)$.

Integrating both sides of Equation (2), disregarding an initial condition $y_{0}$, we get:

\footnotetext{
${ }^{11}$ United Nations Conference on Trade and Development (UNCTAD) estimates that the stock of FDI outflows intra BRICS is only $2.5 \%$ of their total stock of FDI. Indian FDI outflows into the other BRICS is about 3.2\% of India's total FDI, $2.2 \%$ for China and Russia and Brazil have only $0.3 \%$.
} 


$$
\begin{aligned}
y_{t} & =C(1) \sum_{s=0}^{t-1} \epsilon_{t-s}+C^{*}(L) \epsilon_{t} \\
& =T_{t}+C_{t} .
\end{aligned}
$$

Equation (3) is the multivariate version of the Beveridge-Nelson trend-cycle representation (Beveridge \& Nelson 1981). The series $y_{t}$ are represented as sum of a Martingale part $T_{t}=C(1) \sum_{s=0}^{t-1} \epsilon_{t-s}$, which is called the "trend", and a stationary and ergodic part $C_{t}=C^{*}(L) \epsilon_{t}$, which is called the "cycle".

Definition 1. The variables in $y_{t}$ are said to have common trends (or cointegrate) if there are $r$ linearly independent vectors, $r<n$, stacked in an $r \times n$ matrix $\alpha^{\prime}$, with the following property ${ }^{12}$ :

$$
\underset{r \times n}{\alpha} C(1)=0 .
$$

Definition 2. The variables in $y_{t}$ are said to have common cycles if there are $s$ linearly independent vectors, $s \leq n-r$, stacked in an $s \times n$ matrix $\tilde{\alpha}^{\prime}$, with the property that:

$$
\underset{s \times n}{\tilde{\alpha}^{\prime}} C^{*}(L)=0 .
$$

Thus, cointegration and common cycles represent restrictions on the elements of $C(1)$ and $C^{*}(L)$, respectively.

We now discuss what role these restrictions play on the dynamic autoregressive representation of $y_{t}$. We assume that $y_{t}$ is generated by a Vector Autoregression (VAR). Note that VARs are the working horses of time-series econometric analysis. They have been applied extensively for reduced-form and structural-form estimation and forecasting, since they fit most macroeconomic and financial data fairly well:

$$
y_{t}=\Gamma_{1} y_{t-1}+\ldots+\Gamma_{p} y_{t-p}+\epsilon_{t},
$$

where the autoregressive matrix polynomial is $\Phi(L)=I-\Gamma_{1} L-\Gamma_{2} L^{2}-\ldots-\Gamma_{p} L^{p}$.

If elements of $y_{t}$ cointegrate, then the matrix $\Phi(1)=I-\sum_{i=1}^{p} \Gamma_{i}$ must have less than full rank. In this case, Engle \& Granger (1987) showed that the system (4) can be written as a Vector Error-Correction model (VECM) as:

$$
\Delta y_{t}=\Gamma_{1}^{*} \Delta y_{t-1}+\ldots+\Gamma_{p-1}^{*} \Delta y_{t-p+1}+\gamma \alpha^{\prime} y_{t-1}+\epsilon_{t},
$$

\footnotetext{
${ }^{12}$ This definition could alternatively be expressed in terms of an $n \times r$ matrix $\gamma$, such that:

$$
C(1) \gamma=0 \text {. }
$$
}

The Granger-Representation Theorem (Engle E Granger 1987) shows that if the series in $y_{t}$ are cointegrated, $\alpha$ and $\gamma$ in Equation (5) below satisfy:

$$
\begin{aligned}
C(1) \gamma & =0, \text { and, } \\
\alpha^{\prime} C(1) & =0 .
\end{aligned}
$$


where $\gamma$ and $\alpha$ are full rank matrices of order $n \times r, r$ is the rank of the cointegrating space, $-\left(I-\sum_{i=1}^{p} \Gamma_{i}\right)=\gamma \alpha^{\prime}$, and $\Gamma_{j}^{*}=-\sum_{i=j+1}^{p} \Gamma_{i}, j=1, \ldots, p-1$.

For our purposes, testing for cointegration will be used to verify whether BRICS countries data share common trends (or have long-run comovement). Testing for common trends among $y_{t}$ will use the maximum-likelihood approach in Johansen (1991).

A key issue to assure that inference is done properly in this case is to estimate the lag length of the VAR (4) consistently, i.e., to estimate $p$ consistently. When data have common cycles as well as common trends, Athanasopoulos et al. (2011) showed that some popular information criteria do not have an appropriate small-sample behavior, and that a combination of traditional information criteria and criteria with data-dependent penalties can estimate the lag length consistently for VARs with common trends and cycles. An alternative to way to infer $p$ is to perform diagnostic testing to rule out the risk of underestimation of $p$, which leads to inconsistent estimates for the parameters in (5).

Vahid \& Engle (1993) show that the dynamic representation of $y_{t}$ may be further restricted if there are white noise independent linear combinations of the series $\Delta y_{t}$, i.e., that the $\Delta y_{t}$ share common cycles. To see this, recall that the cofeature vectors $\tilde{\alpha}_{i}^{\prime}$, stacked in an $s \times n$ matrix $\tilde{\alpha}^{\prime}$, eliminate all serial correlation in $\Delta y_{t}$, i.e. lead to $\tilde{\alpha}^{\prime} \Delta y_{t}=\tilde{\alpha}^{\prime} \epsilon_{t}$. Therefore, they should restrict the elements of (5) as follows:

$$
\begin{aligned}
\tilde{\alpha}^{\prime} \Gamma_{1}^{*} & =\tilde{\alpha}^{\prime} \Gamma_{2}^{*}=\ldots=\tilde{\alpha}^{\prime} \Gamma_{p-1}^{*}=0, \text { and } \\
\tilde{\alpha}^{\prime} \gamma & =0 .
\end{aligned}
$$

Hecq et al. (2006) have labelled the joint restrictions (6) and (7) as strongform serial-correlation common features (SCCF), whereas they call only imposing restrictions (6) as weak-form SCCF. For the latter, notice that we only inherit an unpredictable linear combination of $\Delta y_{t}$ once we control for the long-run deviations $\alpha^{\prime} y_{t-1}$. Hence,

$$
\tilde{\alpha}^{\prime}\left[\Delta y_{t}-\gamma \alpha^{\prime} y_{t-1}\right]=\tilde{\alpha}^{\prime} \epsilon_{t}
$$

We now continue the discussion of common cycles in the case of strongform serial-correlation common features, since the weak-form case can be immediately inferred from it. As is well known, cofeature vectors are identified only up to an invertible transformation ${ }^{13}$. Without loss of generality, consider $\tilde{\alpha}$ to have an $s$ dimensional identity sub-matrix:

$$
\tilde{\alpha}=\left[\begin{array}{c}
I_{s} \\
\tilde{\alpha}_{(n-s) \times s}^{*}
\end{array}\right] .
$$

Now, $\tilde{\alpha}^{\prime} \Delta y_{t}=\tilde{\alpha}^{\prime} \epsilon_{t}$ constitute $s$ equations in a system. Completing the system by adding the unconstrained VECM equations for the remaining $n-s$ elements of $\Delta y_{t}$, we obtain,

\footnotetext{
${ }^{13}$ The same is true regarding cointegrating vectors. We are only able to identify a subspace of $\mathbb{R}^{n}$ of dimension $r$.
} 


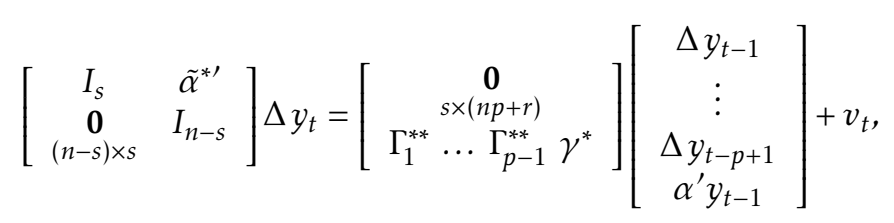

where $v_{t}=\left[\begin{array}{cc}I_{s} & \tilde{\alpha}^{* \prime} \\ \mathbf{0} & I_{n-s}\end{array}\right] \epsilon_{t}$, and $\Gamma_{i}^{* *}$ and $\gamma^{*}$ represent the partitions of $\Gamma_{i}^{*}$ and $\gamma$ respectively, corresponding to the bottom $n-s$ reduced form VECM equations.

It is easy to show that (9) parsimoniously encompasses (5). Since $\left[\begin{array}{cc}I_{s} & \tilde{\alpha}^{* \prime} \\ \mathbf{0} & I_{n-s}\end{array}\right]$ is invertible, it is possible to recover (5) from (9). Notice however that the latter has $s \cdot(n p+r)-s \cdot(n-s)$ fewer parameters.

Assuming that $y_{t}$ share common trends and cycles leading to (9), we test for common cycles using a canonical-correlation approach once we determine what the lag length of the VAR, i.e., $p$, is. We proceed as follows:

1. Compute the sample squared canonical correlations between $\left\{\Delta y_{t}\right\}$ and $\left\{\alpha^{\prime} y_{t-1}, \Delta y_{t-1}, \Delta y_{t-2}, \cdots, \Delta y_{t-p+1}\right\}$, labelled $\lambda_{i}, i=1, \cdots, n$, where $n$ is the number of variables in the system.

2. Test whether the first smallest $s$ canonical correlations are jointly zero by computing the test statistic:

$$
-T \sum_{i=1}^{s} \log \left(1-\lambda_{i}\right)
$$

which has a limiting $\chi^{2}$ distribution with $s(n p+r)-s(n-s)$ degrees of freedom under the null, where $r$ is the number of cointegrating relationships. The maximum number of zero canonical correlations that can possibly exist is $n-r$.

3. Suppose that $s$ zero canonical correlations were found in the previous step. Use these $s$ contemporaneous relationships between the first differences as $s$ pseudo-structural equations in a system of simultaneous equations. Augment them with $n-s$ equations from the VECM and estimate the system using full information maximum likelihood (FIML). The restricted VECM will be the reduced form of this pseudo-structural system.

4. The case where we have weak-form restrictions, in step 1 above, we compute the sample squared canonical correlations between $\left\{\left(\Delta y_{t}^{\prime},\left(\alpha^{\prime} y_{t-1}\right)^{\prime}\right)^{\prime}\right\}$ and $\left\{\alpha^{\prime} y_{t-1}, \Delta y_{t-1}, \Delta y_{t-2}, \cdots, \Delta y_{t-p+1}\right\}$. The rest of the steps remain identical.

\subsection{GMM Based Common-Cycle Tests}

One possible drawback of the canonical-correlation approach is that it assumes homoskedastic data, and that may not hold for BRICS countries data 
collected at high frequency. In this case, a GMM approach is more robust, since inference can be conducted with Heteroskedastic and Auto-Correlation (HAC) robust estimates of variance-covariance matrices of parameter estimates. Regarding common cycles, the system with $n$-equations in (9) can be estimated by GMM. The vector of instruments comprise the series in $\alpha^{\prime} y_{t-1}$, $\Delta y_{t-1}, \Delta y_{t-2}, \cdots, \Delta y_{t-p+1}$, collected in a vector $Z_{t-1}$. GMM estimation and testing exploit the following moment restriction:

$$
\begin{aligned}
& \mathbf{0}=\mathbb{E}\left[v_{t} \otimes Z_{t-1}\right]=
\end{aligned}
$$

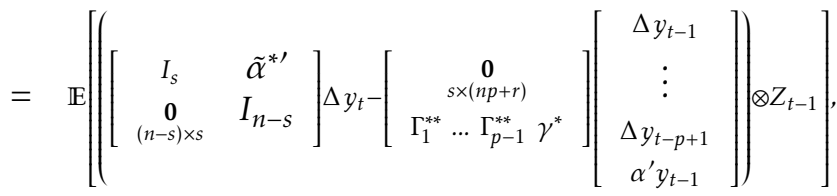

i.e., the orthogonality between all the elements in $v_{t}$ and all the elements in $Z_{t-1}$.

The test for common cycles is an over-identifying restriction test - the $J$ test proposed in Hansen (1982) - which has an asymptotic $\chi^{2}$ distribution with degrees of freedom equal to the number of over-identifying restrictions. The over-identifying restrictions test checks whether the errors of the system are orthogonal to all the instruments in $Z_{t-1}$. Thus, it checks whether the exclusions of the elements of $Z_{t-1}$ in the first $s$ equations are appropriate. Heuristically, since the cyclical behavior (serial correlation behavior) of the data $\Delta y_{t}$ is captured by $Z_{t-1}$, this test verifies whether the linear combinations in these $s$ equations have no serial correlation, i.e., are unpredictable. Therefore, it is a test of common serial correlation or common cycles. If two series have a common cycle, their impulse response functions are colinear, making their response to shocks proportional and therefore, similar. Here, contrary to the canonical correlation approach above, we can deal with heteroskedasticity of unknown form by employing the HAC robust estimates for the variancecovariance matrix of sample means counterparts of (9) $\left(\widehat{S_{T}}\right)$ using the Newey $\&$ West (1987) procedure. The parameters estimated by GMM, stacked in a vector $\theta$, comprise all parameters in $\tilde{\alpha}^{* \prime}$ and all parameters in the matrices $\Gamma_{1}^{* *}, \Gamma_{2}^{* *}, \ldots \Gamma_{p-1}^{* *}$, and in $\gamma^{*}$.

If we want to test for weak-form SCCF, the only additional twist is that now $v_{t}$ takes the form:

$$
v_{t}=\left[\begin{array}{cc}
I_{s} & \tilde{\alpha}^{* \prime} \\
\mathbf{0} & I_{n-s}
\end{array}\right] \Delta y_{t}-\left[\begin{array}{cccc}
\mathbf{0} & \cdots & \mathbf{0} & \gamma_{1} \\
\Gamma_{1}^{* *} & \cdots & \Gamma_{p-1}^{* *} & \gamma_{2}
\end{array}\right]\left[\begin{array}{c}
\Delta y_{t-1} \\
\vdots \\
\Delta y_{t-p+1} \\
\alpha^{\prime} y_{t-1}
\end{array}\right]
$$

where $\gamma=\left[\begin{array}{l}\gamma_{1} \\ \gamma_{2}\end{array}\right]$ 


\section{Empirical analysis}

\subsection{BRICS Countries Data}

In testing for common cycles within BRICS countries, we employ data from several sources at different frequencies. Monthly industrial production for the period 2000M02:2014M09 is provided by the World Bank, and is seasonally adjusted. Monthly exports and imports from 1995M01:2014M09 are also provided by the World Bank in real terms (quantum), and are seasonally adjusted as well. Quarterly household consumption and government expenditures for the period 1995Q1:2014Q2 are provided by the International Monetary Fund (IMF), through the International Financial Statistics (IFS) Database, and are also seasonally adjusted. Quarterly investment from 1999Q1:2014Q2 is also provided by the International Monetary Fund (IMF) after adding both gross fixed capital formation and change in inventories, and is seasonally adjusted. Consumption, government and investment data is sketchy, since it is only available for Brazil, China (Hong Kong), Russia, and South Africa. Quarterly real gross domestic product (GDP) for the period 2000Q1:2014Q1, is also provided by the IMF (IFS), and seasonally adjusted. Date in all levels were transformed by using the logarithmic transformation.

The data used cover the great recession that started in 2008. During this period, growth rates fell sharply and, thus, these series contains outliers. Our approach here is to employ econometric techniques that allow for estimation and testing using robust methods. A good example is the use of GMM - based estimation, when the variance-covariance matrix of sample moments are estimated using heteroskedasticity and autocorrelation consistent (H.A.C.) or "robust" methods. This yields consistent and optimal estimates in large samples, which can be used in testing for synchronicity of cycles for BRICS countries.

In that regard, we employ as large a sample as we could possibly use in the time-series dimension. Hence, events like the Great Recession would have a diluted influence on parameter estimates, and H.A.C. robust methods would allow the proper weighting of existing moment conditions. For example, we employ monthly industrial production from 2000M02:2014M09 - a total of 177 observations; monthly exports and imports from 1995M01:2014M09 a total of 237 observations. These are relatively large samples from a timeseries perspective. Even when we employ quarterly observations, we use the largest possible sample: for household consumption and government expenditures, we used the period 1995Q1 to 2014Q2, a total of 78 observations.

Table 2 presents the correlation matrix for the GDP growth rate. Except for India, BRICS countries have correlation around 0.5. Russia-South Africa and Russia-Euro zone have the highest correlation of the sample - with 0.72 and 0.66 , respectively. The correlations involving India are close to zero and, furthermore, some of them have a negative correlation.

A visual analysis can illustrate the high correlation between Russia and South Africa. Figure 1 presents the growth rate of GDP of Russia and South Africa.

The growth rate of household consumption is presented in Table 3. Brazil, Hong Kong, Russia and South Africa correlate around 0.2, only South Africa and Brazil have correlations below 0.1. United State and Euro zone have negative correlation to Brazil, Russia and South Africa.

Table 4 presents the correlation of the growth rate of industrial production. 
Table 2: Matrix correlation of growth rate of the real GDP from 2000Q1 and 2014Q1

\begin{tabular}{lcccccccr}
\hline \multicolumn{7}{c}{ Real GDP - quarterly data $2000 Q 1: 2014 Q 1$} \\
\hline Country & BRA & CHN & HKG & IND & RUS & ZAF & USA & EURO \\
\hline BRA & 1.00 & 0.41 & 0.56 & -0.05 & 0.57 & 0.50 & 0.39 & 0.49 \\
CHN & - & 1.00 & 0.52 & -0.06 & 0.32 & 0.27 & 0.29 & 0.19 \\
HKG & - & - & 1.00 & 0.03 & 0.51 & 0.46 & 0.47 & 0.50 \\
IND & - & - & - & 1.00 & 0.02 & -0.04 & -0.17 & -0.06 \\
RUS & - & - & - & - & 1.00 & 0.72 & 0.59 & 0.66 \\
ZAF & - & - & - & - & - & 1.00 & 0.49 & 0.58 \\
USA & - & - & - & - & - & - & 1.00 & 0.36 \\
EURO & - & - & - & - & - & - & - & 1.00 \\
\hline
\end{tabular}

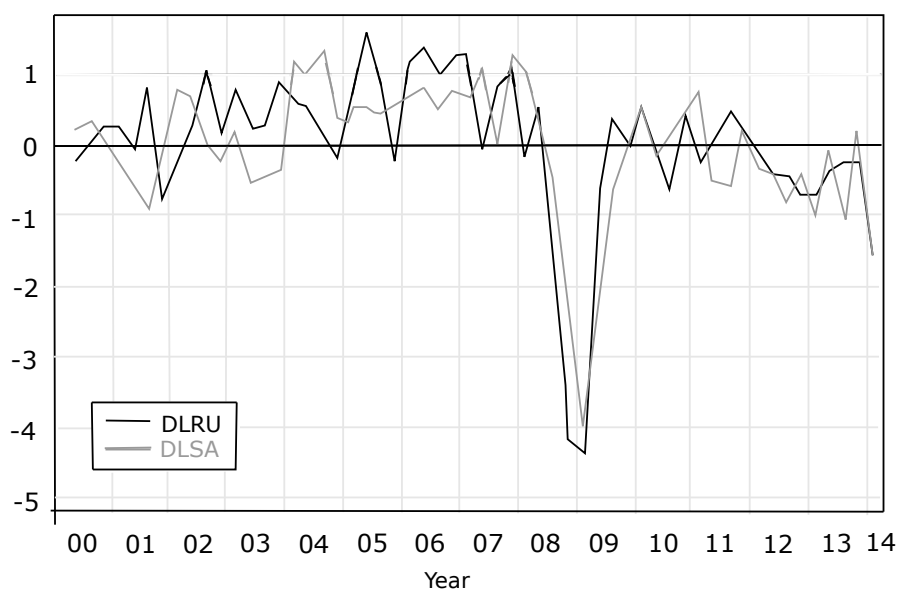

Figure 1: Growth rate of the real GDP for Russia and South Africa from 2000Q1 to 2014Q1

Table 3: Matrix correlation of growth rate of the real household consumption from 1995Q1 to 2014Q2

\begin{tabular}{lccccrr}
\hline \multicolumn{6}{c}{ Household Consumption - quarterly data } & 1995Q1:2014Q2 \\
\hline Country & BRA & HKG & RUS & ZAF & USA & EURO \\
\hline BRA & 1.00 & 0.21 & 0.21 & 0.004 & -0.14 & -0.13 \\
HKG & - & 1.00 & 0.16 & 0.180 & 0.13 & 0.14 \\
RUS & - & - & 1.00 & 0.290 & -0.09 & -0.06 \\
ZAF & - & - & - & 1.000 & 0.34 & -0.04 \\
USA & - & - & - & - & 1.00 & 0.39 \\
EURO & - & - & - & - & - & 1.00 \\
\hline
\end{tabular}


The BRICS have correlation around 0.12. India and South Africa have the highest correlation between the BRICS countries. Euro zone and World have a high correlation with the BRICS countries, which have an average of 0.26 and 0.38 , respectively.

Table 4: Matrix correlation of the industrial production growth rate from 2000M02 to 2014M09

\begin{tabular}{lcccccccc}
\hline \multicolumn{7}{c}{ Industrial Production - monthly data 2000M02:2014M09 } \\
\hline Country & BRA & CHN & IND & RUS & ZAF & USA & EURO & WORLD \\
\hline BRA & 1.00 & 0.01 & 0.17 & 0.07 & 0.13 & 0.15 & 0.29 & 0.35 \\
CHN & - & 1.00 & 0.13 & 0.15 & 0.06 & 0.05 & 0.23 & 0.38 \\
IND & - & - & 1.00 & 0.14 & 0.20 & 0.12 & 0.17 & 0.32 \\
RUS & - & - & - & 1.00 & 0.17 & 0.12 & 0.31 & 0.46 \\
ZAF & - & - & - & - & 1.00 & 0.01 & 0.31 & 0.41 \\
USA & - & - & - & - & - & 1.00 & 0.32 & 0.48 \\
EURO & - & - & - & - & - & - & 1.00 & 0.77 \\
WORLD & - & - & - & - & - & - & - & 1.00 \\
\hline
\end{tabular}

\subsection{Bivariate Analysis: Cointegration and Common Cycles for BRICS Countries}

We start our investigation of the presence of common cycles for BRICS countries data by initially fitting a VAR in levels with unforecastable errors, such as (4). It is key here not to under-parameterize the VAR model, since this leads to misspecification and invalidates inference. Bivariate cointegration leading to (5) is investigated using the technique in Johansen (1991). Results are not reported here in full. Conditional on the potential existence of cointegration, we then perform a GMM based common-cycle test expoiting (10) - a $J$-statistic over-identifying restriction test proposed in Hansen (1982). If the null of validity of the over-identifying restrictions is not rejected, we then find a common cycle among the pair of countries under investigation. In Table 5, we present the results of common trends and/or common cycles for each pair of countries.

Results of common-cycle tests for GDP are presented in Table 5. At 5\% or $10 \%$ significance - the usual levels -, we find common cycles for every country pair - for both strong and weak-form common cycles. Results for country pairs involving India must be regarded with some care, since the serial dependence of the growth rate of India's GDP is very weak. Indeed, India's (logged) GDP can be reasonably well approximated by a random walk with drift. So, growth cycles are unpredictable in this case. Only Brazil-China, Brazil-Índia and China-Russia have a common trend, as indicated by the cointegration vector.

In Table 5 we also present the results of common cycle and common trend for the countries of BRICS and the United State and the Eurozone group. Tests indicate that there are cycles common to all pairs of countries and that only China-Eurozone has common trend.

For a more careful analysis, we will study whether there are common cycles and a common trend for the GDP components: household consumption, government expenditures, investment, exports and imports. 
Table 5: Common-cycle tests for real GDP - GMM based

\begin{tabular}{|c|c|c|c|c|c|c|}
\hline \multicolumn{7}{|c|}{ Real GDP } \\
\hline \multirow{2}{*}{$\Delta y_{1, t}$} & \multirow{2}{*}{$\Delta y_{2, t}$} & \multicolumn{2}{|c|}{ Strong-form SCCF } & \multirow{2}{*}{ Cointegration } & \multicolumn{2}{|c|}{ Weak-form SCCF } \\
\hline & & $\widetilde{\alpha}^{*}$ & $J$-statistic & & $\widetilde{\alpha}^{*}$ & $J$-statistic \\
\hline BRA & $\mathrm{CHN}$ & $\begin{array}{l}1.984^{* * *} \\
(0.618)\end{array}$ & $\begin{array}{r}0.0128 \\
{[0.70]}\end{array}$ & $(1,-0.355)$ & $\begin{array}{l}1.520 \\
(1.020)\end{array}$ & $\begin{array}{c}0.018 \\
{[0.33]}\end{array}$ \\
\hline BRA & HKG & $\begin{array}{l}0.520^{* * * *} \\
(0.139)\end{array}$ & $\begin{array}{r}0.0508 \\
{[0.43]}\end{array}$ & - & - & - \\
\hline BRA & IND & $\begin{array}{l}1.160^{* * *} \\
(0.501)\end{array}$ & $\begin{array}{c}0.072 \\
{[0.71]}\end{array}$ & $(1,-0.480)$ & $\begin{array}{l}0.940^{* *} \\
(0.391)\end{array}$ & $\begin{array}{c}0.058 \\
{[0.69]}\end{array}$ \\
\hline BRA & RUS & $\begin{array}{l}0.460^{* * * *} \\
(0.062)\end{array}$ & $\begin{array}{r}0.0435 \\
{[0.50]}\end{array}$ & - & - & - \\
\hline BRA & ZAF & $\begin{array}{l}0.810^{* * *} \\
(0.399)\end{array}$ & $\begin{array}{r}0.0147 \\
{[0.37]}\end{array}$ & - & - & - \\
\hline $\mathrm{CHN}$ & IND & $\begin{array}{l}5.083 \\
(6.055)\end{array}$ & $\begin{array}{r}0.0006 \\
{[0.86]}\end{array}$ & - & - & - \\
\hline $\mathrm{CHN}$ & RUS & $\begin{array}{c}-0.029 \\
(0.108)\end{array}$ & $\begin{array}{c}0.0271 \\
{[0.47]}\end{array}$ & $(1,-2.340)$ & $\begin{array}{l}0.013 \\
(0.106)\end{array}$ & $\begin{array}{c}0.00098 \\
{[0.82]}\end{array}$ \\
\hline $\mathrm{CHN}$ & $\mathrm{ZAF}$ & $\begin{array}{c}-0.440 \\
(0.346)\end{array}$ & $\begin{array}{r}0.0615 \\
{[0.35]}\end{array}$ & - & - & - \\
\hline HKG & $\mathrm{CHN}$ & $\begin{array}{l}0.620^{* *} \\
(0.302)\end{array}$ & $\begin{array}{c}0.109 \\
{[0.58]}\end{array}$ & - & - & - \\
\hline HKG & IND & $\begin{array}{l}0.210 \\
(0.278)\end{array}$ & $\begin{array}{r}0.1349 \\
{[0.21]}\end{array}$ & - & - & - \\
\hline HKG & RUS & $\begin{array}{l}0.320 \\
(0.194)\end{array}$ & $\begin{array}{r}0.0029 \\
{[0.69]}\end{array}$ & - & - & - \\
\hline HKG & ZAF & $\begin{array}{l}0.500 \\
(0.570)\end{array}$ & $\begin{array}{c}0.00003 \\
{[0.97]}\end{array}$ & - & - & - \\
\hline IND & RUS & $\begin{array}{c}-0.018 \\
(0.157)\end{array}$ & $\begin{array}{r}0.0119 \\
{[0.42]}\end{array}$ & - & - & - \\
\hline IND & ZAF & $\begin{array}{l}0.230 \\
(0.396)\end{array}$ & $\begin{array}{c}0.0074 \\
{[0.52]}\end{array}$ & - & - & - \\
\hline RUS & ZAF & $\begin{array}{l}2.260^{* * *} \\
(0.336)\end{array}$ & $\begin{array}{c}0.035 \\
{[0.17]}\end{array}$ & - & - & - \\
\hline
\end{tabular}

Notes: GMM estimation using Equation (11) for Strong-form SCCF and the analogue equation for Weak-form SCCF.

Robust Standard Errors (HAC) are in parentheses and p-values are in brackets.

${ }^{* * *},{ }^{* *},{ }^{*}$ denote significance at 1 percent, 5 percent, and 10 percent levels, respectively. 
Table 5: Common-cycle tests for real GDP - GMM based (continuation)

\begin{tabular}{|c|c|c|c|c|c|c|}
\hline \multicolumn{7}{|c|}{ Real GDP } \\
\hline \multirow{2}{*}{$\Delta y_{1, t}$} & \multirow{2}{*}{$\Delta y_{2, t}$} & \multicolumn{2}{|c|}{ Strong-form SCCF } & \multirow{2}{*}{ Cointegration } & \multicolumn{2}{|c|}{ Weak-form SCCF } \\
\hline & & $\widetilde{\alpha}^{*}$ & $J$-statistic & & $\widetilde{\alpha}^{*}$ & $J$-statistic \\
\hline BRA & USA & $\begin{array}{l}1.580^{* * * *} \\
(0.301)\end{array}$ & $\begin{array}{l}0.081 \\
{[0.22]}\end{array}$ & - & - & - \\
\hline $\mathrm{CHN}$ & USA & $\begin{array}{l}0.120 \\
(0.214)\end{array}$ & $\begin{array}{l}0.154 \\
{[0.33]}\end{array}$ & - & - & - \\
\hline HKG & USA & $\begin{array}{l}4.130^{* *} \\
(2.191)\end{array}$ & $\begin{array}{l}0.045 \\
{[0.11]}\end{array}$ & - & - & - \\
\hline IND & USA & $\begin{array}{c}-0.340 \\
(0.325)\end{array}$ & $\begin{array}{l}0.020 \\
{[0.29]}\end{array}$ & - & - & - \\
\hline RUS & USA & $\begin{array}{r}-0.038^{*} \\
(0.020)\end{array}$ & $\begin{array}{l}0.039 \\
{[0.55]}\end{array}$ & - & - & - \\
\hline ZAF & USA & $\begin{array}{l}2.070^{* * *} \\
(0.744)\end{array}$ & $\begin{array}{l}0.043 \\
{[0.12]}\end{array}$ & - & - & - \\
\hline BRA & Euro area & $\begin{array}{l}0.440 \\
(0.303)\end{array}$ & $\begin{array}{l}0.102 \\
{[0.62]}\end{array}$ & - & - & - \\
\hline $\mathrm{CHN}$ & Euro area & $\begin{array}{l}0.270^{* *} \\
(0.123)\end{array}$ & $\begin{array}{l}0.165 \\
{[0.38]}\end{array}$ & $(1,-8.300)$ & $\begin{array}{l}0.420^{* * * *} \\
(0.129)\end{array}$ & $\begin{array}{l}0.131 \\
{[0.45]}\end{array}$ \\
\hline HKG & Euro area & $\begin{array}{l}0.730 \\
(0.454)\end{array}$ & $\begin{array}{l}0.001 \\
{[0.83]}\end{array}$ & - & - & - \\
\hline IND & Euro area & $\begin{array}{l}0.130 \\
(0.354)\end{array}$ & $\begin{array}{l}0.081 \\
{[0.23]}\end{array}$ & - & - & - \\
\hline RUS & Euro area & $\begin{array}{l}2.340^{* * * *} \\
(0.221)\end{array}$ & $\begin{array}{l}0.070 \\
{[0.29]}\end{array}$ & - & - & - \\
\hline ZAF & Euro area & $\begin{array}{l}0.860^{* * * *} \\
(0.243)\end{array}$ & $\begin{array}{l}0.030 \\
{[0.20]}\end{array}$ & - & - & - \\
\hline
\end{tabular}


Table 6 presents the results for household consumption. Despite the sketchiness of consumption data, results show a similarity of cyclical consumption growth among all countries for which we have data, which is in line with our findings from GDP. The Russia-South Africa pair has common cyles at $5 \%$ while the remaining pairs of BRICS countries have common cycles at 10 $\%$ significance. Tests for Euro zone and the United state also indicate, for all pairs, common cycles at $5 \%$. When we look for $10 \%$ significance, only South Africa-Eurozone do not have common cycles. The results for weakform SCCF confirm the results for strong-form at 10\%.

Among the BRICS countries, we do not find long-term relationships for the series of consumption. Brazil-Eurozone, Hong Kong-Eurozone and RussiaEurozone showed long-term relationships.

Table 6: Common-cycle tests for real household consumption - GMM based

\begin{tabular}{|c|c|c|c|c|c|c|}
\hline \multicolumn{7}{|c|}{ Household Consumption } \\
\hline \multirow{2}{*}{$\Delta y_{1, t}$} & \multirow{2}{*}{$\Delta y_{2, t}$} & \multicolumn{2}{|c|}{ Strong-form SCCF } & \multirow{2}{*}{ Cointegration } & \multicolumn{2}{|c|}{ Weak-form SCCF } \\
\hline & & $\widetilde{\alpha}^{*}$ & $J$-statistic & & $\widetilde{\alpha}^{*}$ & $J$-statistic \\
\hline BRA & HKG & $\begin{array}{l}0.520 \\
(0.389)\end{array}$ & $\begin{array}{l}0.005 \\
{[0.55]}\end{array}$ & - & - & - \\
\hline BRA & RUS & $\begin{array}{c}-0.470^{* *} \\
(0.219)\end{array}$ & $\begin{array}{l}0.0047 \\
{[0.55]}\end{array}$ & - & - & - \\
\hline BRA & ZAF & $\begin{array}{l}0.210 \\
(0.234)\end{array}$ & $\begin{array}{l}0.00079 \\
{[0.81]}\end{array}$ & - & - & - \\
\hline HKG & RUS & $\begin{array}{l}0.160^{* *} \\
(0.061)\end{array}$ & $\begin{array}{l}0.0998 \\
{[0.62]}\end{array}$ & - & - & - \\
\hline HKG & ZAF & $\begin{array}{l}0.880^{* *} \\
(0.413)\end{array}$ & $\begin{array}{l}0.0069 \\
{[0.47]}\end{array}$ & - & - & - \\
\hline RUS & ZAF & $\begin{array}{l}0.490 \\
(0.603)\end{array}$ & $\begin{array}{c}0.047 \\
{[0.06]}\end{array}$ & - & - & - \\
\hline BRA & USA & $\begin{array}{l}0.310 \\
(0.223)\end{array}$ & $\begin{array}{l}0.165 \\
{[0.72]}\end{array}$ & - & - & - \\
\hline HKG & USA & $\begin{array}{c}-0.880^{* * * *} \\
(0.270)\end{array}$ & $\begin{array}{l}0.168 \\
{[0.71]}\end{array}$ & - & - & - \\
\hline RUS & USA & $\begin{array}{l}0.630 \\
(0.680)\end{array}$ & $\begin{array}{l}0.0898 \\
{[0.48]}\end{array}$ & - & - & - \\
\hline ZAF & USA & $\begin{array}{l}1.710^{* * *} \\
(0.265)\end{array}$ & $\begin{array}{l}0.078 \\
{[0.33]}\end{array}$ & - & - & - \\
\hline BRA & Euro area & $\begin{array}{l}-0.160 \\
(0.224)\end{array}$ & $\begin{array}{l}0.039 \\
{[0.88]}\end{array}$ & $(1,3.82)$ & $\begin{array}{c}-0.160 \\
(0.25)\end{array}$ & $\begin{array}{l}0.039 \\
{[0.79]}\end{array}$ \\
\hline HKG & Euro area & $\begin{array}{c}-0.310 \\
(0.622)\end{array}$ & $\begin{array}{l}0.016 \\
{[0.60]}\end{array}$ & $(1,5.51)$ & $\begin{array}{c}-0.083 \\
(0.82)\end{array}$ & $\begin{array}{l}0.015 \\
{[0.34]}\end{array}$ \\
\hline RUS & Euro area & $\begin{array}{c}-0.050 \\
(0.425)\end{array}$ & $\begin{array}{l}0.1198 \\
{[0.11]}\end{array}$ & $(1,-13.02)$ & $\begin{array}{l}0.999 \\
(0.73)\end{array}$ & $\begin{array}{l}0.029 \\
{[0.62]}\end{array}$ \\
\hline ZAF & Euro area & $\begin{array}{l}1.740^{* * *} \\
(0.443)\end{array}$ & $\begin{array}{l}0.112 \\
{[0.07]}\end{array}$ & - & - & - \\
\hline
\end{tabular}

Notes: GMM estimation using Equation (11) for Strong-form SCCF and the analogue equation for Weak-form SCCF.

Robust Standard Errors (HAC) are in parentheses and p-values are in brackets.

$* * * * *, *$ denote significance at 1 percent, 5 percent, and 10 percent levels, respectively.

Investment results are presented in Table 7. Again, all pairs of countries indicate common cycles at $5 \%$ significance. Besides that, the series of BrazilRussia and Russia-South Africa cointegrate according to the test proposed by Johansen (1991).

The government expenditures also follow the same line of the results for the GDP. Table 8 presents this fact. For Brazil-Hong Kong and Brazil-United 
Table 7: Common-cycle tests for investment - GMM based

\begin{tabular}{|c|c|c|c|c|c|c|}
\hline \multicolumn{7}{|c|}{ Investment } \\
\hline \multirow{2}{*}{$\Delta y_{1, t}$} & \multirow{2}{*}{$\Delta y_{2, t}$} & \multicolumn{2}{|c|}{ Strong-form SCCF } & \multirow{2}{*}{ Cointegration } & \multicolumn{2}{|c|}{ Weak-form SCCF } \\
\hline & & $\widetilde{\alpha}^{*}$ & $J$-statistic & & $\widetilde{\alpha}^{*}$ & $J$-statistic \\
\hline BRA & HKG & $\begin{array}{c}-0.360^{* *} \\
(0.145)\end{array}$ & $\begin{array}{c}0.042 \\
{[0.93]}\end{array}$ & - & - & - \\
\hline BRA & RUS & $\begin{array}{r}-0.050 \\
(0.131)\end{array}$ & $\begin{array}{l}0.093 \\
{[0.50]}\end{array}$ & $(1,-1.36)$ & $\begin{array}{l}0.250 \\
(0.204)\end{array}$ & $\begin{array}{c}0.100 \\
{[0.33]}\end{array}$ \\
\hline BRA & ZAF & $\begin{array}{l}0.590 \\
(0.389)\end{array}$ & $\begin{array}{l}0.029 \\
{[0.18]}\end{array}$ & - & - & - \\
\hline HKG & RUS & $\begin{array}{c}-1.210^{* * *} \\
(0.471)\end{array}$ & $\begin{array}{l}0.0499 \\
{[0.90]}\end{array}$ & - & - & - \\
\hline HKG & ZAF & $\begin{array}{r}-0.370 \\
(0.366)\end{array}$ & $\begin{array}{l}0.0290 \\
{[0.63]}\end{array}$ & - & - & - \\
\hline RUS & ZAF & $\begin{array}{c}-2.400^{* * *} \\
(1.104)\end{array}$ & $\begin{array}{l}0.013 \\
{[0.68]}\end{array}$ & $(1,-1.05)$ & $\begin{array}{r}-7.570 \\
(8.440)\end{array}$ & $\begin{array}{c}0.002 \\
{[0.76]}\end{array}$ \\
\hline BRA & USA & $\begin{array}{l}0.310 \\
(0.524)\end{array}$ & $\begin{array}{l}0.084 \\
0.31\end{array}$ & - & - & - \\
\hline HKG & USA & $\begin{array}{l}0.970 \\
(0.765)\end{array}$ & $\begin{array}{l}0.125 \\
{[0.20]}\end{array}$ & - & - & - \\
\hline RUS & USA & $\begin{array}{l}0.320 \\
(1.080)\end{array}$ & $\begin{array}{l}0.013 \\
{[0.38]}\end{array}$ & - & - & - \\
\hline ZAF & USA & $\begin{array}{l}1.065^{* *} \\
(0.494)\end{array}$ & $\begin{array}{c}0.033 \\
{[0.16]}\end{array}$ & - & - & - \\
\hline
\end{tabular}

Notes: GMM estimation using Equation (11) for Strong-form SCCF and the analogue equation for Weak-form SCCF.

Robust Standard Errors (HAC) are in parentheses and p-values are in brackets.

$* * *, * *, *$ denote significance at 1 percent, 5 percent, and 10 percent levels, respectively.

States, there is no common cycles at $10 \%$, but we accept the hypothesis of common cyles at $5 \%$ significance. Despite the abstence of strong form SCCF at $10 \%$ for Brazil-United States pair, we accept the hypothesis of common cycles for the weak form at $10 \%$.

Tables 9 and 10 present, respectively, results for Imports and Exports at the monthly frequency. We get a completely different picture here: with the exception of three cases ${ }^{14}$, there is no common cycle among Exports and Imports for pairs of BRICS countries. This result holds even when we test weakform SCCF. The results of exports for Brazil-Russia can be explained because both countries are commodity exporters and the analyzed period matches the commodities boom.

Finally, we study the monthly data of industrial production. Since we want to compare results between commodities super cycle period (2000-2014) and its previous period, Table 11 is divided into two different samples. Panel A shows the results for the 2000M02:2014:M09 period while, Panel B shows the results for the period 1995M08:2000M01 ${ }^{15}$.

Panel A shows that, at $10 \%$ significance only the pairs Brazil-India, IndiaRussia and Russia-South Africa have no common cycles. Of these, RussiaSouth Africa presents common cycles at $5 \%$. We can also see that the rejection of the hypothesis of common cycles to pairs that include India is not inherent only to the countries of BRICS. Tests for India-USA, India-Eurozone and India-World also reject the hypothesis of common cycles at $10 \%$. This con-

\footnotetext{
${ }^{14}$ Imports for Brazil-Russia and for China-Russia and exports for Brazil-Russia.

${ }^{15}$ Brazil does not appear in Panel B because there are no data for this country in the World Bank database.
} 
Table 8: Common-cycle tests for government expenditures - GMM based

\begin{tabular}{|c|c|c|c|c|c|c|}
\hline \multicolumn{7}{|c|}{ Government expenditures } \\
\hline \multirow{2}{*}{$\Delta y_{1, t}$} & \multirow{2}{*}{$\Delta y_{2, t}$} & \multicolumn{2}{|c|}{ Strong-form SCCF } & \multirow{2}{*}{ Cointegration } & \multicolumn{2}{|c|}{ Weak-form SCCF } \\
\hline & & $\widetilde{\alpha}^{*}$ & $J$-statistic & & $\widetilde{\alpha}^{*}$ & $J$-statistic \\
\hline BRA & HKG & $\begin{array}{l}1.020 \\
(1.388)\end{array}$ & $\begin{array}{l}0.045 \\
{[0.07]}\end{array}$ & - & - & - \\
\hline BRA & RUS & $\begin{array}{c}-0.360^{* * * *} \\
(0.128)\end{array}$ & $\begin{array}{c}0.082 \\
{[0.30]}\end{array}$ & - & - & - \\
\hline BRA & $\mathrm{ZAF}$ & $\begin{array}{l}0.370 \\
(0.246)\end{array}$ & $\begin{array}{l}0.146 \\
{[0.10]}\end{array}$ & $(1,-0.95)$ & $\begin{array}{l}0.500^{* *} \\
(0.253)\end{array}$ & $\begin{array}{l}0.105 \\
{[0.17]}\end{array}$ \\
\hline HKG & RUS & $\begin{array}{l}0.150^{* * * *} \\
(0.043)\end{array}$ & $\begin{array}{c}0.132 \\
{[0.76]}\end{array}$ & - & - & - \\
\hline HKG & $\mathrm{ZAF}$ & $\begin{array}{l}0.310 \\
(0.203)\end{array}$ & $\begin{array}{l}0.040 \\
{[0.39]}\end{array}$ & - & - & - \\
\hline RUS & ZAF & $\begin{array}{l}0.860^{* * * *} \\
(0.324)\end{array}$ & $\begin{array}{c}0.063 \\
{[0.46]}\end{array}$ & - & - & - \\
\hline BRA & USA & $\begin{array}{l}0.380 \\
(0.373)\end{array}$ & $\begin{array}{l}0.073 \\
{[0.06]}\end{array}$ & $(1,-0.62)$ & $\begin{array}{c}-5.380 \\
(3.333)\end{array}$ & $\begin{array}{l}0.005 \\
{[0.52]}\end{array}$ \\
\hline HKG & USA & $\begin{array}{c}-0.025 \\
(0.325)\end{array}$ & $\begin{array}{c}0.064 \\
{[0.45]}\end{array}$ & - & - & - \\
\hline RUS & USA & $\begin{array}{l}0.870 \\
(0.662)\end{array}$ & $\begin{array}{c}0.016 \\
{[0.95]}\end{array}$ & - & - & - \\
\hline ZAF & USA & $\begin{array}{l}0.370 \\
(0.252)\end{array}$ & $\begin{array}{c}0.138 \\
{[0.26]}\end{array}$ & $(1,-1.07)$ & $\begin{array}{l}-4.100^{* * * *} \\
(1.093)\end{array}$ & $\begin{array}{l}0.050 \\
{[0.82]}\end{array}$ \\
\hline
\end{tabular}

Notes: GMM estimation using Equation (11) for Strong-form SCCF and the analogue equation for Weak-form SCCF.

Robust Standard Errors (HAC) are in parentheses and p-values are in brackets.

$* * *, * *, *$ denote significance at 1 percent, 5 percent, and 10 percent levels, respectively.

Table 9: Common-cycle tests for imports - GMM based

\begin{tabular}{|c|c|c|c|c|c|c|}
\hline \multicolumn{7}{|c|}{ Imports } \\
\hline \multirow{2}{*}{$\Delta y_{1, t}$} & \multirow{2}{*}{$\Delta y_{2, t}$} & \multicolumn{2}{|c|}{ Strong-form SCCF } & \multirow{2}{*}{ Cointegration } & \multicolumn{2}{|c|}{ Weak-form SCCF } \\
\hline & & $\widetilde{\alpha}^{*}$ & $J$-statistic & & $\widetilde{\alpha}^{*}$ & $J$-statistic \\
\hline BRA & $\mathrm{CHN}$ & $\begin{array}{c}0.500^{* * * *} \\
(0.189)\end{array}$ & $\begin{array}{c}0.062 \\
{[0.002]}\end{array}$ & - & - & - \\
\hline BRA & IND & $\begin{array}{c}0.814^{* * * *} \\
(0.177)\end{array}$ & $\begin{array}{l}0.092 \\
{[0.03]}\end{array}$ & - & - & - \\
\hline BRA & RUS & $\begin{array}{c}1.570^{* * * *} \\
(0.292)\end{array}$ & $\begin{array}{l}0.030 \\
{[0.21]}\end{array}$ & - & - & - \\
\hline BRA & ZAF & $\begin{array}{c}0.399^{* * *} \\
(0.127)\end{array}$ & $\begin{array}{c}0.074 \\
{[0.0006]}\end{array}$ & - & - & - \\
\hline $\mathrm{CHN}$ & IND & $\begin{array}{c}0.620^{* * * *} \\
(0.206)\end{array}$ & $\begin{array}{c}0.060 \\
{[0.003]}\end{array}$ & - & - & - \\
\hline $\mathrm{CHN}$ & RUS & $\begin{array}{c}0.770^{* * * *} \\
(0.035)\end{array}$ & $\begin{array}{l}0.054 \\
{[0.79]}\end{array}$ & - & - & - \\
\hline $\mathrm{CHN}$ & ZAF & $\begin{array}{c}0.260^{*} \\
(0.136)\end{array}$ & $\begin{array}{c}0.068 \\
{[0.001]}\end{array}$ & - & - & - \\
\hline IND & RUS & $\begin{array}{c}0.810^{* * * *} \\
(0.189)\end{array}$ & $\begin{array}{l}0.0997 \\
{[0.018]}\end{array}$ & - & - & - \\
\hline IND & ZAF & $\begin{array}{c}0.370^{* * * *} \\
(0.095)\end{array}$ & $\begin{array}{l}0.067 \\
{[0.001]}\end{array}$ & - & - & - \\
\hline RUS & ZAF & $\begin{array}{c}0.220^{* * *} \\
(0.060)\end{array}$ & $\begin{array}{c}0.075 \\
{[0.004]}\end{array}$ & - & - & - \\
\hline
\end{tabular}

Notes: GMM estimation using Equation (11) for Strong-form SCCF and the analogue equation for Weak-form SCCF.

Robust Standard Errors (HAC) are in parentheses and p-values are in brackets.

***, ${ }^{* *},{ }^{*}$ denote significance at 1 percent, 5 percent, and 10 percent levels, respectively. 
Table 10: Common-cycle tests for exports - GMM based

\begin{tabular}{|c|c|c|c|c|c|c|}
\hline \multicolumn{7}{|c|}{ Exports } \\
\hline \multirow{2}{*}{$\Delta y_{1, t}$} & \multirow{2}{*}{$\Delta y_{2, t}$} & \multicolumn{2}{|c|}{ Strong-form SCCF } & \multirow{2}{*}{ Cointegration } & \multicolumn{2}{|c|}{ Weak-form SCCF } \\
\hline & & $\widetilde{\alpha}^{*}$ & $J$-statistic & & $\widetilde{\alpha}^{*}$ & $J$-statistic \\
\hline BRA & $\mathrm{CHN}$ & $\begin{array}{l}0.570^{* * * *} \\
(0.171)\end{array}$ & $\begin{array}{r}0.070 \\
{[0.004]}\end{array}$ & $(1,-0.96)$ & $\begin{array}{l}0.750^{* * *} \\
(0.185)\end{array}$ & $\begin{array}{r}0.050 \\
{[0.005]}\end{array}$ \\
\hline BRA & IND & $\begin{array}{l}0.840^{* * *} \\
(0.155)\end{array}$ & $\begin{array}{r}0.060 \\
{[0.018]}\end{array}$ & - & - & - \\
\hline BRA & RUS & $\begin{array}{l}0.480^{* * * *} \\
(0.131)\end{array}$ & $\begin{array}{r}0.081 \\
{[0.240]}\end{array}$ & - & - & - \\
\hline BRA & ZAF & $\begin{array}{l}0.310^{* * * *} \\
(0.066)\end{array}$ & $\begin{array}{r}0.070 \\
{[0.002]}\end{array}$ & $(1,-3.64)$ & $\begin{array}{l}0.400^{* * * *} \\
(0.077)\end{array}$ & $\begin{array}{r}0.070 \\
{[0.001]}\end{array}$ \\
\hline $\mathrm{CHN}$ & IND & $\begin{array}{l}0.130 \\
(0.104)\end{array}$ & $\begin{array}{r}0.080 \\
{[5 E-04]}\end{array}$ & - & - & - \\
\hline $\mathrm{CHN}$ & RUS & $\begin{array}{l}0.700^{* * * *} \\
(0.172)\end{array}$ & $\begin{array}{r}0.080 \\
{[5 E-04]}\end{array}$ & - & - & - \\
\hline $\mathrm{CHN}$ & ZAF & $\begin{array}{r}-0.018 \\
(0.081)\end{array}$ & $\begin{array}{r}0.080 \\
{[0.001]}\end{array}$ & $(1,-3.52)$ & $\begin{array}{l}0.570^{* * *} \\
(0.167)\end{array}$ & $\begin{array}{r}0.076 \\
{[5 E-04]}\end{array}$ \\
\hline RUS & IND & $\begin{array}{l}0.230^{* *} \\
(0.106)\end{array}$ & $\begin{array}{r}0.100 \\
{[9 E-05]}\end{array}$ & $(1,-3.36)$ & $\begin{array}{l}0.600^{* * *} \\
(0.131)\end{array}$ & $\begin{array}{c}0.042 \\
{[0.020]}\end{array}$ \\
\hline RUS & ZAF & $\begin{array}{l}0.180^{* *} \\
(0.065)\end{array}$ & $\begin{array}{r}0.090 \\
{[3 E-04]}\end{array}$ & $(1,-0.42)$ & $\begin{array}{l}0.540^{* *} \\
(0.097)\end{array}$ & $\begin{array}{c}0.050 \\
{[0.007]}\end{array}$ \\
\hline IND & ZAF & $\begin{array}{l}0.130^{* *} \\
(0.058)\end{array}$ & $\begin{array}{r}0.070 \\
{[0.003]}\end{array}$ & $(1,-1.37)$ & $\begin{array}{l}0.310^{* * * *} \\
(0.093)\end{array}$ & $\begin{array}{r}0.060 \\
{[6 E-04]}\end{array}$ \\
\hline
\end{tabular}

Notes: GMM estimation using Equation (11) for Strong-form SCCF and the analogue equation for Weak-form SCCF.

Robust Standard Errors (HAC) are in parentheses and p-values are in brackets.

${ }^{* * * *},{ }^{* *},{ }^{*}$ denote significance at 1 percent, 5 percent, and 10 percent levels, respectively.

clusion holds for Brazil-India and India-Eurozone even when we tested the weak-form common-cyclical features. If we apply the same tests using the 1995M08:2000M01 sample (Panel B), we find some different results. There was strong evidence of synchronicity of IND-RUS, RUS-ZAF and RUS-US pairs.

An interesting point to note is that we can not make a qualitative analysis of short-term dynamics associated with series. In Table 4, the pairs involving India had higher correlation than the other pairs of BRICS. In particular, the correlation between Brazil-India was the second largest correlation between the BRICS (0.17); however, as we have seen, Brazil-India does not have common cycles.

Table 12 presents the correlation between cycles $^{16}$ of industrial production growth rates. Although the correlation between the growth rate is low between the BRICS, the correlation cycles of this series is high. Moreover, we can also note that the correlation of cycles between the BRICS and other groups of countries are closer than the correlation between the growth rate.

Figure 2 confirms the results of common cycles tests for the Brazil-South Africa pair. Although, visually, the series does not appear to have short-term relationships (Figure 2(a)), when we separate the cycle parts we see that there is a relationship between the cycles of the series (Figure 2(b)).

\subsection{Multivariate Analysis: Cointegration and Common Cycles for BRICS Countries Data}

In this section, we will do the tests for common cycles for the BRICS. As we have a small sample, we could not make the common test cycles between the

\footnotetext{
${ }^{16}$ The cycles were made using the Hodrick-Prescott filter.
} 
Table 11: Common-cycle tests for industrial production - GMM based

\begin{tabular}{|c|c|c|c|c|c|c|}
\hline \multirow{2}{*}{$\Delta y_{1, t}$} & \multirow{2}{*}{$\Delta y_{2, t}$} & \multicolumn{2}{|c|}{ Strong-form SCCF } & \multirow{2}{*}{ Cointegration } & \multicolumn{2}{|c|}{ Weak-form SCCF } \\
\hline & & $\widetilde{\alpha}^{*}$ & $J$-statistic & & $\widetilde{\alpha}^{*}$ & $J$-statistic \\
\hline \multicolumn{7}{|c|}{ Panel A: Sample: 2000M02:2014M09 } \\
\hline BRA & $\mathrm{CHN}$ & $\begin{array}{c}-2.120^{* * *} \\
(0.638)\end{array}$ & $\begin{array}{r}0.066 \\
{[0.066]}\end{array}$ & - & - & - \\
\hline BRA & IND & $\begin{array}{c}-0.090 \\
(0.210)\end{array}$ & $\begin{array}{l}0.066 \\
{[0.02]}\end{array}$ & $(1,-0.36)$ & $\begin{array}{c}0.080 \\
(0.206)\end{array}$ & $\begin{array}{l}0.052 \\
{[0.03]}\end{array}$ \\
\hline BRA & RUS & $\begin{array}{c}-0.120 \\
(0.227)\end{array}$ & $\begin{array}{l}0.064 \\
{[0.44]}\end{array}$ & - & - & - \\
\hline BRA & ZAF & $\begin{array}{r}-0.060 \\
(0.049)\end{array}$ & $\begin{array}{l}0.054 \\
{[0.61]}\end{array}$ & - & - & - \\
\hline $\mathrm{CHN}$ & IND & $\begin{array}{c}-0.230^{* * * *} \\
(0.081)\end{array}$ & $\begin{array}{l}0.050 \\
{[0.13]}\end{array}$ & - & - & - \\
\hline $\mathrm{CHN}$ & RUS & $\begin{array}{l}0.201^{* * *} \\
(0.071)\end{array}$ & $\begin{array}{c}0.059 \\
{[0.19]}\end{array}$ & - & - & - \\
\hline $\mathrm{CHN}$ & $\mathrm{ZAF}$ & $\begin{array}{c}-0.002 \\
(0.017)\end{array}$ & $\begin{array}{l}0.103 \\
{[0.1]}\end{array}$ & - & - & - \\
\hline IND & RUS & $\begin{array}{r}-0.640 \\
(0.458)\end{array}$ & $\begin{array}{c}0.034 \\
{[0.02]}\end{array}$ & - & - & - \\
\hline IND & ZAF & $\begin{array}{l}0.150^{*} \\
(0.088)\end{array}$ & $\begin{array}{l}0.047 \\
{[0.15]}\end{array}$ & - & - & - \\
\hline RUS & ZAF & $\begin{array}{l}0.150^{* * *} \\
(0.058)\end{array}$ & $\begin{array}{c}0.064 \\
{[0.051]}\end{array}$ & - & - & - \\
\hline BRA & USA & $\begin{array}{r}-0.540^{*} \\
(0.301)\end{array}$ & $\begin{array}{c}0.078 \\
{[0.28]}\end{array}$ & - & - & - \\
\hline $\mathrm{CHN}$ & USA & $\begin{array}{l}0.760^{* * * *} \\
(0.238)\end{array}$ & $\begin{array}{l}0.027 \\
{[0.46]}\end{array}$ & - & - & - \\
\hline IND & USA & $\begin{array}{r}-0.140 \\
(0.403)\end{array}$ & $\begin{array}{c}0.076 \\
{[0.07]}\end{array}$ & - & - & - \\
\hline RUS & USA & $\begin{array}{l}0.300 \\
(0.370)\end{array}$ & $\begin{array}{r}0.071 \\
{[0.006]}\end{array}$ & - & - & - \\
\hline ZAF & USA & $\begin{array}{r}-0.080 \\
(0.500)\end{array}$ & $\begin{array}{l}0.115 \\
{[0.11]}\end{array}$ & - & - & - \\
\hline BRA & Euro area & $\begin{array}{r}-0.060 \\
(0.154)\end{array}$ & $\begin{array}{l}0.0004 \\
{[0.66]}\end{array}$ & - & - & - \\
\hline $\mathrm{CHN}$ & Euro area & $\begin{array}{l}0.230^{* * *} \\
(0.106)\end{array}$ & $\begin{array}{l}0.043 \\
{[0.19]}\end{array}$ & - & - & - \\
\hline IND & Euro area & $\begin{array}{c}-0.150 \\
(0.136)\end{array}$ & $\begin{array}{c}0.097 \\
{[0.01]}\end{array}$ & $(1,-0.04)$ & $\begin{array}{c}-0.200 \\
(0.138)\end{array}$ & $\begin{array}{l}0.089 \\
{[0.01]}\end{array}$ \\
\hline RUS & Euro area & $\begin{array}{l}0.072 \\
(0.130)\end{array}$ & $\begin{array}{r}0.086 \\
{[0.104]}\end{array}$ & - & - & - \\
\hline ZAF & Euro area & $\begin{array}{l}2.090^{* * * *} \\
(0.460)\end{array}$ & $\begin{array}{l}0.100 \\
{[0.12]}\end{array}$ & - & - & - \\
\hline
\end{tabular}


Table 11: Common-cycle tests for industrial production - GMM based (continuation)

\begin{tabular}{|c|c|c|c|c|c|c|}
\hline \multirow{2}{*}{$\Delta y_{1, t}$} & \multirow{2}{*}{$\Delta y_{2, t}$} & \multicolumn{2}{|c|}{ Strong-form SCCF } & \multirow{2}{*}{ Cointegration } & \multicolumn{2}{|c|}{ Weak-form SCCF } \\
\hline & & $\widetilde{\alpha}^{*}$ & $J$-statistic & & $\widetilde{\alpha}^{*}$ & $J$-statistic \\
\hline
\end{tabular}

Panel A: Sample: 2000M02:2014M09

\begin{tabular}{|c|c|c|c|c|c|c|}
\hline BRA & World & $\begin{array}{l}2.300^{* * * *} \\
(0.365)\end{array}$ & $\begin{array}{c}0.119 \\
{[0.28]}\end{array}$ & - & - & - \\
\hline $\mathrm{CHN}$ & World & $\begin{array}{l}0.370^{* * * *} \\
(0.123)\end{array}$ & $\begin{array}{l}0.049 \\
{[0.21]}\end{array}$ & $(1,-4.17)$ & $\begin{array}{c}-0.010^{* *} \\
(0.004)\end{array}$ & $\begin{array}{c}0.028 \\
{[0.44]}\end{array}$ \\
\hline IND & World & $\begin{array}{l}0.490^{* *} \\
(0.218)\end{array}$ & $\begin{array}{c}0.061 \\
{[0.02]}\end{array}$ & - & - & - \\
\hline RUS & World & $\begin{array}{l}0.090 \\
(0.324)\end{array}$ & $\begin{array}{c}0.075 \\
{[0.08]}\end{array}$ & - & - & - \\
\hline ZAF & World & $\begin{array}{l}8.390^{* * * *} \\
(1.602)\end{array}$ & $\begin{array}{l}0.051 \\
{[0.67]}\end{array}$ & - & - & - \\
\hline
\end{tabular}

Panel B: Sample: 1995M08:2000M01

\begin{tabular}{|c|c|c|c|c|c|c|}
\hline $\mathrm{CHN}$ & IND & $\begin{array}{l}0.035 \\
(0.069)\end{array}$ & $\begin{array}{c}0.087 \\
{[0.50]}\end{array}$ & - & - & - \\
\hline $\mathrm{CHN}$ & RUS & $\begin{array}{l}0.028 \\
(0.071)\end{array}$ & $\begin{array}{c}0.074 \\
{[0.59]}\end{array}$ & - & - & - \\
\hline $\mathrm{CHN}$ & ZAF & $\begin{array}{l}0.019 \\
(0.042)\end{array}$ & $\begin{array}{l}0.059 \\
{[0.39]}\end{array}$ & - & - & - \\
\hline IND & RUS & $\begin{array}{c}-0.520 \\
(0.376)\end{array}$ & $\begin{array}{l}0.116 \\
{[0.12]}\end{array}$ & - & - & - \\
\hline IND & ZAF & $\begin{array}{l}0.438^{* * *} \\
(0.158)\end{array}$ & $\begin{array}{l}0.101 \\
{[0.16]}\end{array}$ & - & - & - \\
\hline RUS & ZAF & $\begin{array}{l}0.137 \\
(0.135)\end{array}$ & $\begin{array}{l}0.035 \\
{[0.62]}\end{array}$ & - & - & - \\
\hline $\mathrm{CHN}$ & USA & $\begin{array}{l}1.146^{*} \\
(0.623)\end{array}$ & $\begin{array}{c}0.115 \\
{[0.33]}\end{array}$ & - & - & - \\
\hline IND & USA & $\begin{array}{r}-3.880 \\
(2.403)\end{array}$ & $\begin{array}{c}0.092 \\
{[0.03]}\end{array}$ & - & - & - \\
\hline RUS & USA & $\begin{array}{c}-0.124 \\
(2.490)\end{array}$ & $\begin{array}{c}0.034 \\
{[0.18]}\end{array}$ & - & - & - \\
\hline ZAF & USA & $\begin{array}{l}0.115 \\
(1.430)\end{array}$ & $\begin{array}{l}0.108 \\
{[0.14]}\end{array}$ & - & - & - \\
\hline
\end{tabular}

Notes: GMM estimation using Equation (11) for Strong-form SCCF and the analogue equation for Weak-form SCCF.

Robust Standard Errors (HAC) are in parentheses and p-values are in brackets.

$* * * * * * *$ denote significance at 1 percent, 5 percent, and 10 percent levels, respectively. 
Table 12: Matrix correlation between industrial production growth rate cycles from 2000M02 to 2014M09 - Based on the Hodrick-Prescott filter

\begin{tabular}{|c|c|c|c|c|c|c|c|c|}
\hline \multicolumn{9}{|c|}{ Industrial Production - monthly data 2000M02:2014M09 } \\
\hline Country & BRA & $\mathrm{CHN}$ & IND & RUS & ZAF & USA & EURO & WORLD \\
\hline BRA & 1.00 & 0.56 & 0.60 & 0.60 & 0.63 & 0.59 & 0.65 & 0.71 \\
\hline $\mathrm{CHN}$ & - & 1.00 & 0.67 & 0.67 & 0.43 & 0.62 & 0.61 & 0.74 \\
\hline IND & - & - & 1.00 & 0.65 & 0.54 & 0.66 & 0.68 & 0.74 \\
\hline RUS & - & - & - & 1.00 & 0.63 & 0.76 & 0.81 & 0.85 \\
\hline ZAF & - & - & - & - & 1.00 & 0.68 & 0.73 & 0.73 \\
\hline USA & - & - & - & - & - & 1.00 & 0.89 & 0.93 \\
\hline EURO & - & - & - & - & - & - & 1.00 & 0.94 \\
\hline WORLD & - & - & - & - & - & - & - & 1.00 \\
\hline
\end{tabular}

Figure 2: (a) Growth rate of the industrial production from 2000M02 to 2014M09. (b) Growth rate cycle of the industrial production from 2000M02 to 2014M09 Based on the Hodrick-Prescott filter
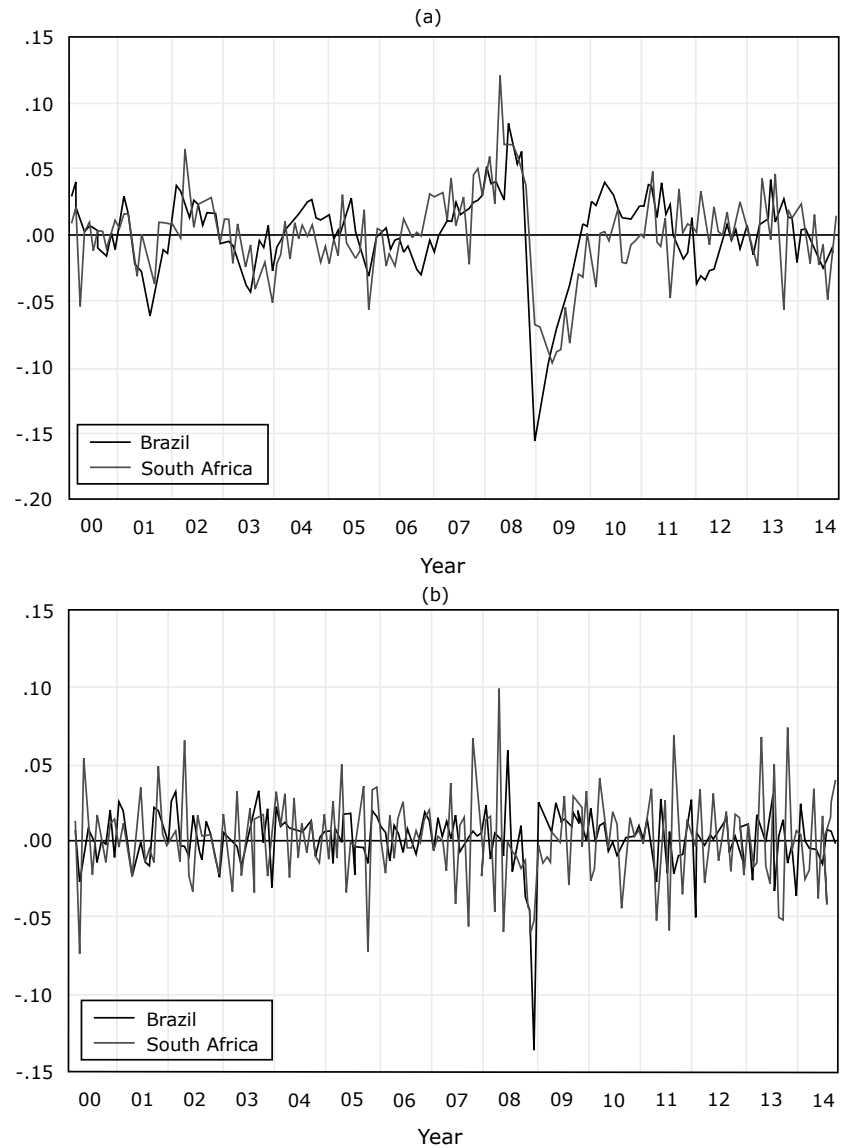
BRICS and other groups of countries. Besides that, the analysis is only made for the GDP series, household consumption and industrial production.

The challenge of this section remains to properly estimate the common cyclical-feature restrictions. We have a similar picture of bivariate analyses. We find common cycles among the BRICS for the three series described above. Industrial Production and real GDP has 4 cofeatures vectors, while household consumption has 3 cofeatures vectors. These results indicate that the shortterm dynamics between the members of the BRICS group has a common component ${ }^{17}$. Table 13 presents the results for the multivariate test. Only the GDP series presented a long-term relationship as shown by the error correction vector.

The common-cycle-feature restrictions bring better econometric treatability for the series, because the number of parameters to be estimated is less than the model without restrictions. For example, for industrial production, the vector autoregressive (VAR) without restriction with 3 lags have 80 parameters to be estimated. When the restrictions are incorporated, the number of parameters falls from 80 to 24 .

Figure 3 illustrates the cycles of industrial production obtained through the Hodrick-Prescott filter and helps to visualize the result of common cycles displayed in Table 13.

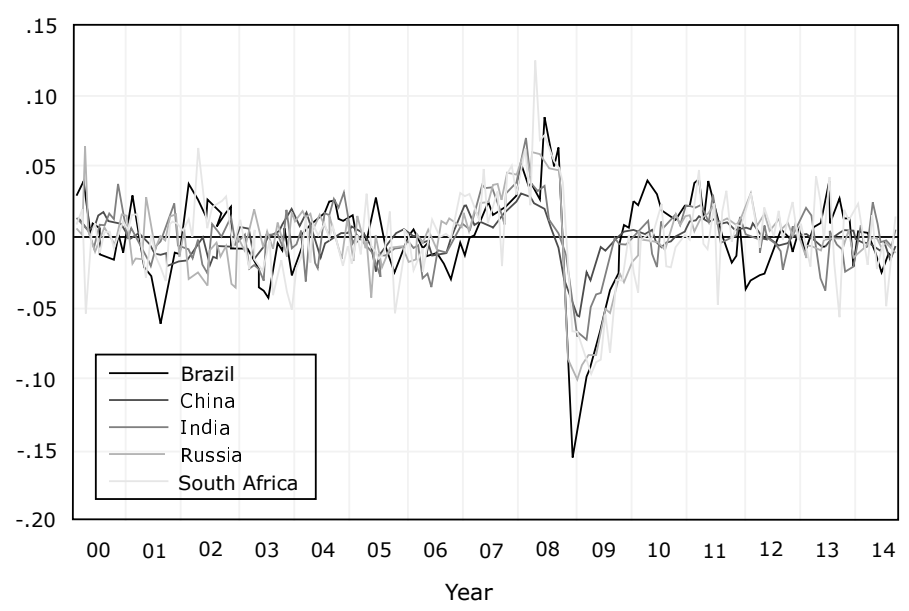

Figure 3: Growth rate cycle of the industrial production from 2000M02 to 2014M09 - Based on the Hodrick-Prescott filter

\section{Conclusion and Further Research}

In this paper, we propose studying the possible similarities among BRICS countries by using an integrated approach that models the short and the longrun behaviors of member countries jointly. Specifically, we employ tests of synchronicity of cycles of key economic variables of the BRICS countries, put forward by the common-trend and common-cycle approach of Engle \& Kozicki (1993), Vahid \& Engle (1993, 1997), Engle \& Issler (1995), Issler \& Vahid

\footnotetext{
${ }^{17}$ Note that the result for the household consumption series must to be interpreted with some caution, since, for the period under review, we have data only for Brazil, Hong Kong, Russia and South Africa.
} 
Table 13: Common-cycle tests multivariate - GMM based

\begin{tabular}{|c|c|c|c|}
\hline \multicolumn{4}{|c|}{ Multivariate Common-cycle tests } \\
\hline \multirow{4}{*}{ Null Hipothes: Number of cofeature vector $(s)$} & \multicolumn{3}{|c|}{$J$-statistic of Strong-form SCCF } \\
\hline & \multirow{2}{*}{\multicolumn{2}{|c|}{$\Delta y_{t}=(\mathbf{B R A}, \mathbf{C H N}, \mathbf{I N D}, \mathbf{R U S}, \mathrm{ZAF})$}} & \multirow{3}{*}{$\frac{\Delta y_{t}=(\text { BRA, CHN, RUS, ZAF })}{\text { Household Consumption }}$} \\
\hline & & & \\
\hline & Industrial Production & Real GDP & \\
\hline$s=1$ & $\begin{array}{l}0.057 \\
{[0.55]}\end{array}$ & $\begin{array}{c}0.00066 \\
{[0.85]}\end{array}$ & $\begin{array}{l}0.004 \\
{[0.57]}\end{array}$ \\
\hline$s=2$ & $\begin{array}{l}0.139 \\
{[0.46]}\end{array}$ & $\begin{array}{l}0.064 \\
{[0.75]}\end{array}$ & $\begin{array}{l}0.065 \\
{[0.30]}\end{array}$ \\
\hline$s=3$ & $\begin{array}{l}0.166 \\
{[0.89]}\end{array}$ & $\begin{array}{l}0.175 \\
{[0.65]}\end{array}$ & $\begin{array}{l}0.112 \\
{[0.49]}\end{array}$ \\
\hline $\mathrm{s}=4$ & $\begin{array}{l}0.179 \\
{[0.99]}\end{array}$ & $\begin{array}{l}0.174 \\
{[0.98]}\end{array}$ & - \\
\hline Cointegration & - & $(1,0.96,-1.5,0.16,-0.75)$ & - \\
\hline
\end{tabular}

Notes: the p-values are in brackets. 
(2001, 2006), Vahid \& Issler (2002), Hecq et al. (2006), and Athanasopoulos et al. (2011). In this setup, non-stationary economic series are decomposed into an integrated trend component and a stationary and ergodic cyclical component, where their properties can be jointly investigated in a unified multivariate setting based on vector autoregressive (VAR) models. Trends and cycles can be common to a group of series being modelled, and these common features can be removed by independent linear combination.

Our exaustive econometric tests found that BRICS countries have similar gross domestic product (GDP), consumption, investment, and industrial production cycles, which is in line with previous evidence comparing emerging and developed economies; see, for example, the initial results in Calvo et al. (1993), Engle \& Issler (1993), and, recently, the results in Aiolfi et al. (2011). Our evidence also shows synchronicity between BRICS countries and advanced economies - a result not usually found in the literature. We believe the latter to be a consequence of the choice of sample period in this paper data mostly from 2000 on, or from 1995 on. As we had covered a period of greater economic integration - globalization - it is possible that the economies of most countries analyzed here became more integrated and, therefore, they appear to be more synchronized.

\section{Acknowledgements}

We thank Pedro Ferreira, seminar participants of the "BRICS: Challenges and Opportunities" and an anonymous referee for very helpful suggestions. Issler acknowledges the financial support from CNPq and FAPERJ and Delalibera from FAPERJ. We also thank Marcia Waleria Teles Machado and Andrea Virgínia Machado for the excellent research assistance.

\section{Bibliography}

Aiolfi, M., Catão, L. A. \& Timmermann, A. (2011), 'Common factors in latin america's business cycles', Journal of Development Economics 95(2), 212-228.

Athanasopoulos, G., de Carvalho Guillén, O. T., Issler, J. V. \& Vahid, F. (2011), 'Model selection, estimation and forecasting in var models with short-run and long-run restrictions', Journal of Econometrics 164(1), 116-129.

URL: $h t t p: / / w w w . s c i e n c e d i r e c t . c o m / s c i e n c e / a r t i c l e / p i i / S 0304407611000364$

Beveridge, S. \& Nelson, C. R. (1981), 'A new approach to decomposition of economic time series into permanent and transitory components with particular attention to measurement of the "business cycle "', Journal of Monetary Economics 7(2), 151-174.

Calvo, G. A., Leiderman, L. \& Reinhart, C. M. (1993), 'Capital inflows and real exchange rate appreciation in latin america: the role of external factors', Staff Papers-International Monetary Fund 40(1), 108-151.

Engle, R. F. \& Granger, C. W. J. (1987), 'Co-integration and error correction: Representation, estimation, and testing', Econometrica 55(2), 251-276.

URL: $h t t p: / / w w w . j s t o r . o r g / s t a b l e / 1913236$

Engle, R. F. \& Issler, J. V. (1993), 'Common trends and common cycles in latin america', Revista Brasileira de Economia 47(2), 149-176. 
Engle, R. F. \& Issler, J. V. (1995), 'Estimating common sectoral cycles', Journal of Monetary Economics 35(1), 83-113.

URL: $h t t p: / / w w w . s c i e n c e d i r e c t . c o m / s c i e n c e / a r t i c l e / p i i / 030439329401188 G$

Engle, R. F. \& Kozicki, S. (1993), 'Testing for common features', Journal of Business and Economic Statistics 11(4), 369-380.

URL: http://www.jstor.org/stable/1391623

Freeman, R. B. \& Huang, W. (2015), China's "great leap forward " in science and engineering, Technical report, National Bureau of Economic Research.

Hansen, L. P. (1982), 'Large sample properties of generalized method of moments estimators', Econometrica 50(4), 1029-1054.

URL: $h t t p: / / w w w . j s t o r . o r g / s t a b l e / 1912775$

Hecq, A., Palm, F. C. \& Urbain, J.-P. (2006), 'Common cyclical features analysis in $\{\mathrm{VAR}\}$ models with cointegration', Journal of Econometrics 132(1), 117141. Common Features.

URL: http://www.sciencedirect.com/science/article/pii/S0304407605000436

Issler, J. V., Rodrigues, C. \& Burjack, R. (2014), 'Using common features to understand the behavior of metal-commodity prices and forecast them at different horizons', Journal of International Money and Finance 42, 310-335.

Issler, J. V. \& Vahid, F. (2001), 'Common cycles and the importance of transitory shocks to macroeconomic aggregates', Journal of Monetary Economics $47(3), 449-475$.

URL: http://www.sciencedirect.com/science/article/pii/S0304393201000526

Issler, J. V. \& Vahid, F. (2006), 'The missing link: using the nber recession indicator to construct coincident and leading indices of economic activity', Journal of Econometrics 132(1), 281-303.

URL: http://www.sciencedirect.com/science/article/pii/S0304407605000497

Johansen, S. (1991), 'Estimation and hypothesis testing of cointegration vectors in gaussian vector autoregressive models', Econometrica 59(6), 15511580.

URL: http://www.jstor.org/stable/2938278

Kose, M. A. \& Prasad, E. S. (2010), 'Emerging markets: resilience and growth amid global turmoil (washington: Brookings institution)'.

Newey, W. K. \& West, K. D. (1987), 'Hypothesis testing with efficient method of moments estimation', International Economic Review pp. 777-787.

Vahid, F. \& Engle, R. F. (1993), 'Common trends and common cycles', Journal of Applied Econometrics 8(4), 41-360.

URL: $h t t p: / / w w w . j s t o r . o r g / s t a b l e / 2285000$

Vahid, F. \& Engle, R. F. (1997), 'Codependent cycles', Journal of Econometrics 80(2), 199-221.

URL: $h t t p: / / w w w . s c i e n c e d i r e c t . c o m / s c i e n c e / a r t i c l e / p i i / S 0304407697000328$ 
Vahid, F. \& Issler, J. V. (2002), 'The importance of common cyclical features in var analysis: a monte-carlo study', Journal of Econometrics 109(2), 341363.

URL: http://www.sciencedirect.com/science/article/pii/S0304407602001173

Veloso, F., Ferreira, P. \& Pessoa, S. (2013), 'Experiências comparadas de crescimento econômico no pós-guerra', Desenvolvimento Econômico - Uma Perspectiva Brasileira. Rio de Janeiro: Campus/Elsevier pp. 3-38. 